\title{
Development of Fundamental Basic Movement Skill of Children
}

\author{
Yanuar Kiram $^{1 *}$, Anton Komaini ${ }^{1}$, Nuridin Widya Pranoto ${ }^{1}$ \\ ${ }^{1}$ Faculty of Sport Science, Universitas Negeri Padang, Indonesia \\ "Corresponding author. Email: anton_chzicho@yahoo.com
}

\begin{abstract}
The aim of this study is to develop models of motor learning for kindergarten which adapts to the curriculum and characteristics of the students. This research used Research and Development method. Limited-scale trials were conducted on 20 kindergarten studentsin Padang Utara. Field trials were conducted on 35 students from two differents kindergarden. The instrument used to collect the data were general interviews instructions, field notes, evaluation sheet, scale validation questionaire, students assesment rubrics, game observation guideline, and game effectiveness observation guideline. Based on the data analysis it can be concluded that: (1) fundamental gross motor skill model for Kindergarten students in group A comprises of warming up activities, content proper and cooling down activities. (2) The model is arrange ina guide book entitled Games for Motor Skills (3) the gross motor learning model for kindergarten students is effective and is in accordance with the curriculum and characteristics of kindergarten children which can be used for learning gross motor skills.
\end{abstract}

\section{Keywords: Fundamental Motor Skills, Kindergarten Students}

\section{INTRODUCTION}

Kids' motor is interesting to be discussed, it is dominant for kids. The result of observation shown 70-80 $\%$ kids did the motor in their learning process through plaing approach. Kids are very active, then, motor and learning about motor is important. It should be the main attention too. The correct applying of motor will give the contribution into kids' growth. Based on the explanation above, one of the important components to extend in education is the motor potency. Motor is defined as the person quality which can be improved by motor activity. The motoric development purposes to introduce and train the smooth and heavy motion.

Fife years old is the golden age for motor growth. Childhood is the proper time to learn motor potency. It is supported by some reasons; first, kids' body is more flexible than adult body, they will be easy to receive all lessons about motor. Second, they have bit skill already, they will learn new thing easily. Third, kids are brave to try something new. In this age they have great ability to learn, especially in earlier age. Considering it is the golden age, the kids' growth has to be optimized. They can grow optimally if they have health body, good nutritions and good education. Kids grow from some aspects; physical, heavy or smooth motor, cognitive, social and emotional.Physical motoric aspect is the standard to stimulate students' basic motor. The correct stimulant which is appropriate with growth and development will optimize the learning result.
Learning fundamental motor skill by learn through bodies activities which involve big muscles. It is also gain to improve kids' physical potency in daily life activities. The learning process can be done by physical activities such as run or jump. Generally, the learning process is effectively done by playing (game). It is interesting for kids because it makes them relax and no pressure. "The kinds of playing must be suitable for kids' ability and should give education. Unsuitable playing can give bad impact towards kids' growth, physicaly or mentality" [1].

"Result about kids' motion skill as follow; 5.06\% students motor skill is in too little category, $13.92 \%$ is in less category, $22.15 \%$ is in middle category, $37.34 \%$ is in good category, and $21.15 \%$ is in good category. It means some of kids students are in low middle category. For example, there are students who cannot jump with their feet, catch ball without their hands, and cannot stand on kidtoes, cannot catch ball with hands, have no balance and cannot bounchback or roll the ball" [2]

The problems are caused by some factors, such as less of school tools, less of learning model for basic motor, less understanding of teachers, less variations in playing ways, teachers' less understaning about fundamental motor learning step and students' less enthusiastic in learning fundamental motor. This research finding is also supported by observation result in kids' learning problem asthe following table 1 . 
Tabel 1.Kindergarten Problems in Padang

\begin{tabular}{|l|l|l|l|l|}
\hline \multirow{2}{*}{ No } & \multirow{2}{*}{ Problem } & \multicolumn{3}{|c|}{ Criteria } \\
\cline { 3 - 5 } & $\begin{array}{l}\text { Fundamental } \\
\text { motor skills }\end{array}$ & & & \\
\hline 2 & $\begin{array}{l}\text { The students' } \\
\text { motor } \\
\text { willingness }\end{array}$ & & & \\
\hline 3 & $\begin{array}{l}\text { Teachers' } \\
\text { understanding of } \\
\text { Fundamental } \\
\text { motor skills step }\end{array}$ & & & \\
\hline 4 & $\begin{array}{l}\text { Standardized of } \\
\text { fundamental } \\
\text { motor skill } \\
\text { learning }\end{array}$ & & & \\
\hline 5 & $\begin{array}{l}\text { Optimalization } \\
\text { of Fundamental } \\
\text { motor skills }\end{array}$ & & & \\
\hline 6 & $\begin{array}{l}\text { Variation of } \\
\text { Fundamental } \\
\text { motor skills }\end{array}$ & & & \\
\hline
\end{tabular}

From this research can be summarized that there are some problems occurs in leraning fundamental motor skills. It is caused by less variation in learning model. It is seen from the theachers' difficulties to find the model of learning, especially in fundamental motor skill. The students also seem reluctant to do the motor or passive durung teaching learning process. In addition, Unorganized in applying learning model step makes the leraning process uneffectively. The sequences of learning are still unprogrammed. Then, less standardization in fundamental motor skill found by the unsuitable achievement learning motor as the government is expected. The last but not list, the developing of learning model in fundamental motor skills is less of mximum. In fact, kinds of learning model are less of variations.

From the problems above, the researcher is get interest to give the solution through making leraning model of fundamental motor skills based on traditional game. Why the researcher bases in traditional game, the reason is to make easier in applying, more cheerful, and the important thing is to conserve the traditional game. It is culture heirloom which involves majesty values. "The majesty values are reflected by the spirit and game philosophy" [3]. Traditional game is the game played by the kids in the past which use all tools and nature facilities. That's why the researcher intends to research about "The Developing Students' Motor Skills Model'.

\section{METHODOLOGY}

The researcher uses the Development research. The procedures are; Sugiyono (2011) states some procedures in development research. It consists of some steps as follw:

(1) knowing the potency and problem (2) data collecting (3) product design (4) validation design (5) revise design (6) product trial (7) product revise (8) usage trial (9) product revise. The population of the research is the students of Kindergarten in Padang district. Thie research is conducted in Samudra Kindergarten North Padan. The instrument of the research is fundamental motor skills test (Komaini: 2017)

\section{RESULT}

\section{Necessary Analyzing}

Necessary analysing is the way to extract the main problem through direct observation. In the research of learning fundamental motor skills, the analyzing is done to the kindergarten in north Padang. The observation done by some ways like interview towards students, teachers and parents, and also observed teaching learning process about fundamental motor skills directly.

Based on the observation can be conluded some information for instances, students feel bored with the games used in motor learning, the teacher difficulties in finding learning model for motor skills, less of learning model which is used nature as media.From the problems, the researcher will develop the learning model for motor skills in Kindergarten. The making process will be adjusted with curriculum, by then the students get easier in receiving lessons.

\section{Description of Draft Product}

Description earlier draft product is the draft planning which will be used. In this resserach, the draft consists of ten learning motor models bases animal. (1) guess animal (2) snake finding food (3) running cheetah, (4) find animal, (5) take animal, (6) kangaroo jumping, (7) white egret jumping, (8) mouse hole, (9) cattle fish, (10) antlion.

\section{The Data of Small Scale Trial}

After the earlier draft getting validation, the next step to be done is small scale trial. In this research, the researcher tried in Samudra Kindergarten with 20 students whom taught by two teachers. There are three datas resulted from this research; (1) data of motor learning model observation in Kindergarten, (2) the data of result motor learning model observation in Kindergarten, (3) the data of suggestion for motor learning model observation in Kindergarten.

From this trial, there are ten questions are resulted which will be ask to the expert. In this questions there are four different assessment scales. The data is processed by using Likert scale. The data validation and assessment frequency distributive as follow: 
Tabel 2. The Distribution of Assesment Frequency by Expert and Teacher in every Game in Small Scale Trial

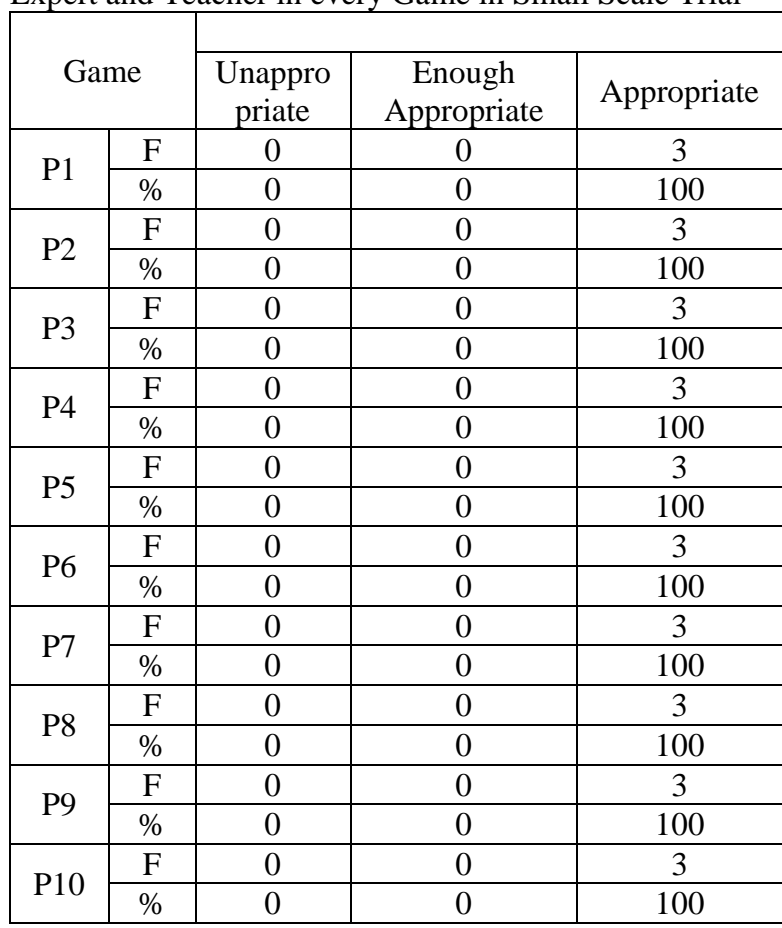

Note:

F: Frequency

$\%$ : Percentage

Based on the table found that the number of score in small scale trial is in interval $35 \leq \mathrm{X}$. Then, data is distributed to the assessment frequency. In the table, the score $35 \leq \mathrm{X}$ is in appropriate category. It means, the observer found that learning model of motor skills in Kindergarten is appropriate.

The Data of the Game Effectiveness in Small Scale Trial

Tabel 2. The Observation Result Data of the Game Effectiveness in Small Scale Trial

Note:

A1: Expert1

A2: Expert 2

G1: Teacher 1

Tabel 3. The Normative and Distributif Frequency Account of Assesment Category Expert and Teacher towards the Game Effectiveness in Small cale Trial.

\begin{tabular}{|l|l|l|l|l|}
\hline Formula & Interval & Category & $\mathrm{F}$ & $\%$ \\
\hline & & Less & 0 & 0 \\
$X<(\mu-1,0 \sigma)$ & $X<25$ & Efektive & & \\
\hline$(\mu-1,0 \sigma) \leq X<$ & $25 \leq X<$ & Enough & 0 & 0 \\
$(\mu+1,0 \sigma)$ & 35 & Efektive & & \\
\hline$(\mu+1,0 \sigma) \leq X$ & $35 \leq X$ & Efektive & 3 & 100 \\
\hline Total & 3 & 100 \\
\hline
\end{tabular}

Note:

$\mathrm{X}$ : the total of subject score

$\mu$ : mean ideal $\sigma:$ standard ofideal devisiation

The table shown that the total score given from three observers is in interval $35 \leq \mathrm{X}$. it means in effective category. Theobservers $(100 \%)$ assest the game for developing in small scale trial is effective to use in teaching learning process.

\section{The Data of Wide Scale Trial}

The small scale trial purposes to do tral with wide scale, with the big subject too. The trial is conducted in two places, in Bhayangkari Kindergarten and Perwari II. In Bhayangkari, the researcher used 15 students whom taught by 2 teachers, and in Perwari II the researcher used 20 students whom taught by one teacher.

Tabel 4. The Distribution of Assesment Frequency by Expert and Teacher in every Game in Wide Scale Trial

\begin{tabular}{|c|c|c|c|c|}
\hline \multirow{2}{*}{\multicolumn{2}{|c|}{$\begin{array}{l}\text { Permainan } \\
\text { (Game) }\end{array}$}} & \multicolumn{3}{|l|}{ Kategori } \\
\hline & & \multirow{2}{*}{$\begin{array}{l}\text { Unapprop } \\
\text { riate }\end{array}$} & \multirow{2}{*}{$\begin{array}{l}\begin{array}{l}\text { Enough } \\
\text { appropriate }\end{array} \\
0\end{array}$} & \multirow{2}{*}{$\begin{array}{l}\text { Appropr } \\
\text { iate } \\
4\end{array}$} \\
\hline & $\mathrm{F}$ & & & \\
\hline PI & $\%$ & 0 & 0 & 100 \\
\hline \multirow{2}{*}{$\mathrm{P} 2$} & $\mathrm{~F}$ & 0 & 0 & 4 \\
\hline & $\%$ & 0 & 0 & 100 \\
\hline \multirow{2}{*}{ P3 } & $\mathrm{F}$ & 0 & 0 & 4 \\
\hline & $\%$ & 0 & 0 & 100 \\
\hline \multirow{2}{*}{ P4 } & $\mathrm{F}$ & 0 & 0 & 4 \\
\hline & $\%$ & 0 & 0 & 100 \\
\hline \multirow{2}{*}{ P5 } & $\mathrm{F}$ & 0 & 0 & 4 \\
\hline & $\%$ & 0 & 0 & 100 \\
\hline \multirow{2}{*}{ P6 } & $\mathrm{F}$ & 0 & 0 & 4 \\
\hline & $\%$ & 0 & 0 & 100 \\
\hline \multirow{2}{*}{ P7 } & $\mathrm{F}$ & 0 & 0 & 4 \\
\hline & $\%$ & 0 & 0 & 100 \\
\hline \multirow{2}{*}{ P8 } & $\mathrm{F}$ & 0 & 0 & 4 \\
\hline & $\%$ & 0 & 0 & 100 \\
\hline \multirow{2}{*}{ P9 } & $\mathrm{F}$ & 0 & 0 & 4 \\
\hline & $\%$ & 0 & 0 & 100 \\
\hline \multirow{2}{*}{ P10 } & $\mathrm{F}$ & 0 & 0 & 4 \\
\hline & $\%$ & 0 & 0 & 100 \\
\hline
\end{tabular}

Note: F : Frequency \%: Percentage

Based on the table can be seen that the score in assessment wide scale trial is in $35 \leq \mathrm{X}$. The data distributed into assessment frequency. From the table of assessment distributive interval, score $35 \leq \mathrm{X}$ is in appropriate category. It means, the observer state that motor learning model is appropriate with the students. The assessment of learning model effectiveness is processed by Likert with distance 1-4. The psikomotor effectiveness is the main to assest based on the Kindergarten curriculum. 
The Data of the Game Effectiveness in Wide Scale Trial

Tabel 5. The Observation Result Data of the Game Effectiveness in Wide Scale Trial

\begin{tabular}{|c|c|c|c|c|c|c|c|c|c|c|c|c|}
\hline \multirow{3}{*}{ Game } & \multirow{3}{*}{$\begin{array}{l}\text { Expert } \\
\text { Code }\end{array}$} & \multicolumn{10}{|c|}{ Satement Number } & \multirow{3}{*}{$\sum$} \\
\hline & & 1 & 2 & 3 & 4 & 5 & 6 & 7 & 8 & 9 & $\begin{array}{l}1 \\
0\end{array}$ & \\
\hline & & \multicolumn{10}{|c|}{ Assesment Result } & \\
\hline \multirow{4}{*}{$\begin{array}{l}10 \\
\text { Game } \\
\text { s }\end{array}$} & A1 & 4 & 4 & 3 & 4 & 4 & 3 & 3 & 4 & 3 & 3 & 35 \\
\hline & A2 & 4 & 3 & 3 & 4 & 3 & 4 & 4 & 3 & 3 & 4 & 35 \\
\hline & G1 & 4 & 4 & 3 & 3 & 4 & 4 & 4 & 3 & 4 & 3 & 36 \\
\hline & $\mathrm{G} 2$ & 4 & 4 & 3 & 3 & 4 & 4 & 4 & 3 & 4 & 4 & 37 \\
\hline
\end{tabular}

Note:

A1: Expert 1

A2: Expert 2

G1: Teacher 1

G2: Teacher 2

Tabel 6. The Normative and Distributif Frequency Account of Assesment Category Expert and Teacher towards the Game Effectiveness in WideScale Trial

\begin{tabular}{|c|c|c|c|c|}
\hline Formula & Interval & $\begin{array}{l}\text { Categor } \\
\mathrm{y}\end{array}$ & $\mathrm{F}$ & $\%$ \\
\hline$X<(\mu-1,0 \sigma)$ & $X<25$ & $\begin{array}{l}\text { Kurang } \\
\text { Efektif }\end{array}$ & 0 & 0 \\
\hline $\begin{array}{l}(\mu-1,0 \sigma) \leq X< \\
(\mu+1,0 \sigma)\end{array}$ & $\begin{array}{l}25 \leq X \\
<35\end{array}$ & $\begin{array}{l}\text { Cukup } \\
\text { Efektif }\end{array}$ & 0 & 0 \\
\hline$(\mu+1,0 \sigma) \leq X$ & $35 \leq \mathrm{X}$ & Efektif & 4 & 100 \\
\hline \multicolumn{5}{|c|}{\begin{tabular}{|l|l|l|} 
Total & 4 & 100 \\
\end{tabular}} \\
\hline
\end{tabular}

Note:

$\mathrm{X}$ : the total of subject score

$\mu$ : mean ideal

$\sigma:$ standard of ideal devisiation

The tabel shown that the total score given by all observers is in $35 \leq \mathrm{X}$. It means in effectivecategory. Allobservers $(100 \%)$ concluded that the game in wide scale is effective to be applied.

\section{CONCLUSION}

Therea are some conclusion found from the research about the developing students' motor skill model in Kindergarten.

The development of learning fundamental motor skills through animal game approach which use research and development method produce ten games as follow: (1) guess animal (2) snake finding food (3) running cheetah, (4) find animal, (5) take animal, (6) kangaroo jumping, (7) white egret jumping, (8) mouse hole, (9) cattle fish, (10) ant-lion.

The development of rough motor skill by adopting animal motor is effective to use in Kindergarten learning process. The development of rough motor skill by adopting animal motor got the good respond from Kindergarten students.

The products of the research can be used for 1) Applying in learning model of fundamental motor skill in Kindergarten,2) The Kindergarten teacher is suggested to use the learning model from the easy step to the complex step, 3) The tools used in applying learning model can be adjusted with school condition.

\section{REFERENCES}

[1] M. Tedjasaputra. "Bermain mainan dan permainan". Jakarta: Gramedia. 2001, pp 12.

[2] A, Komaini, Fundamental Motor Skills of Kindergarten Students (A Survey Study of the Influence of Financial Condition, Playing Activity, and Nutritional Status). IOP Publishing. IOP Conf. Series: Materials Science and Engineering 180 012156 doi:10.1088/1757-899X/180/1/012156. 2017

[3] Y. Kiram. "Belajar Motorik". Padang: FIK UNP. 2000, pp 23. 